\title{
KEMAMPUAN ABSTRAKSI MATEMATIS SISWA SEKOLAH MENENGAH PERTAMA (SMP) KLS VIII
}

\author{
Beni Yusepa, G.P. \\ Program Studi Pendidikan Matematika \\ FKIP Universitas Pasundan \\ pyusepa.fkip.pmat@unpas.ac.id
}

\begin{abstract}
Abstrak: Kemampuan abstraksi matematis merupakan kemampuan dasar yang yang harus dimiliki siswa. Tujuan penelitian ini adalah untuk mendeskripsikan kemampuan abstraksi matematis siswa Sekolah Menengah Pertama (SMP). Metode penelitian ini adalah kualitatif deskriptif. Subyek penelitiannya adalah siswa kelas VIII di salah satu SMP Negeri Kota Bandung sebanyak 33 siswa. Instrumen utama dalam penelitian adalah peneliti sendiri dan dibantu dengan tes kemampuan abstraksi matematis serta pedoman wawancara. Kemampuan abstraksi matematis dalam penelitian ini berkaitan dengan abstraksi reflektif, abstraksi empiris, dan abstraksi teoritis. Pada hasil penelitian ini memberikan saran atau rekomendasi kepada para guru dan peneliti untuk memperhatikan hal-hal berikut dalam pembelajaran, yaitu: 1) pemilihan model atau pendekatan pembelajaran harus tepat sesuai dengan karakteristik materi dan karakteristik siswa; 2) penggunaan bahan ajar lebih mengaktifkan siswa; dan 3) perlu penelitian lanjutan untuk meningkatkan kemampuan abstraksi matematis siswa dengan model pembelajaran yang bervariasi.
\end{abstract}

\section{Kata kunci: kemampuan abstraksi matematis, abstaksi reflektif, abstraksi} empiris, dan abstraksi teoritis

\section{A. PENDAhuluan}

Kemampuan abstraksi matematis merupakan kemampuan yang penting dimiliki oleh siswa. Namun, masih sedikit para peneliti yang memperhatikan kemampuan ini khususnya di Indonesia. Selanjutnya pada bagian pendahuluan ini akan diuraikan tentang latar belakang, rumusan masalah, tujuan penelitian, dan manfaat penelitian.

Membangun konsep matematis secara mandiri oleh siswa merupakan hal yang mendasar dalam pembelajaran matematika. Siswa diberikan kesempatan yang seluas-luasnya untuk membangun dan mengkonstruksi sendiri pengetahuannya. Pembelajaran berorientasi pada masalah dunia nyata yang dimengerti siswa, memungkinkan siswa lebih mudah dalam membangun pengetahuannya sendiri. Menurut Ge \& Land (Hong, Y,.J. \& Kim, K., M; 2016), masalah tidak terstruktur membuat siswa mengaitkan pengetahuan matematika abstrak dengan kehidupan sehari-hari. Dengan demikian, mereka mampu berpikir abstrak, menggeneralisasi, dan menyusun masalah dalam kehidupan sehari-hari.

Berpikir abstrak, menggeneralisasi, dan menyusun malasah dalam kehidupan sehari-hari merupakan proses abstraksi matematis. Menurut Kamii, Kirkland, \& Lewis (Bermejo dan Diaz, 2007), dari kerangka konstruktivis, abstraksi dilihat sebagai sebuah proses dari mulai konkret hingga abstrak dengan level perkembangan. Hasil atau produk dari proses abstraksi 
matematis merupakan kemampuan abstraksi matematis. Namun kenyataannya, kemampuan matematis siswa Indonesia cenderung masih belum sesuai dengan yang diharapkan.

The Program for International Student Assessment (PISA) and the Trends in International Mathematics and Science Study (TIMSS) menunjukkan bahwa prestasi siswa Indonesia masih belum sesuai harapan. Hasil PISA (2015), kemampuan siswa Indonesia dalam matematika berada pada kelompok bawah di atas Brazil, Peru, Libanon, Tunisia, FYROM, Kosovo, Algeria, dan Dominic Republic. Hal ini kurang menggembirakan meskipun belum tentu hasil tes tersebut mewakili secara keseluruhan kemampuan matematis siswa Indonesia.

Berdasarkan uraian yang telah dikemukakan, penulis tertarik untuk melakukan penelitian tentang "Kemampuan abstraksi Matematis Siswa Sekolah Menengah Pertama (SMP) Kelas VIII".

Berdasarkan latar belakang yang telah dikemukakan, rumusan masalah dalam penelitian ini adalah "Bagaimana kemampuan abstraksi matematis siswa SMP kelas VIII pada materi Persamaan Linear Satu Variabel (PLSV)?

Tujuan Penelitian

Tujuan penelitian ini adalah untuk mendeskripsikan kemampuan abstraksi matematis siswa SMP kelas VIII pada materi PLSV.

Manfaat Penelitian

Manfaat penelitian ini adalah sebagai berikut.

1. Bagi peneliti, hasil penelitian ini dapat memberikan informasi tentang kemampuan abstraksi matematis siswa SMP kelas VIII pada materi PLSV.

2. Bagi guru, hasil penelitian ini dapat dijadikan salah satu pedoman dalam menentukan model, strategi, atau pendekatan pembelajaran yang sesuai dalam upaya meningkatkan kualitas pembelajaran sehingga kemampuan abstraksi matematis siswa optimal.

3. Bagi akademisi, hasil penelitian ini diharapkan dapat memberikan kontribusi dalam mengembangkan pembelajaran matematika yang berkualitas.

\section{B. KAJIAN TEORI}

Menurut Van Oers \& Poland (Hong, Y,.J. \& Kim, K. M; 2016), abstraksi adalah proses membangun hubungan antara objek dari sudut pandang tertentu. Piaget (Bermejo dan Diaz, 2007), mencatat dua jenis abstraksi: empiris dan reflektif. Abstraksi empiris fokus pada kandungan tertentu dari sebuah objek dan mengabaikan yang lainnya. Kandungankandungan tersebut dilihat melalui indra dan hanya kandungan yang ingin disimpulkan oleh orangnyalah yang dipilih. Abstraksi reflektif melibatkan hubungan mental antar objek, seperti "beda", "serupa", "dua" (pengetahuan matematis logis). Kandungan dari objek disimpulkan dari aksi mental (berpikir) yang dilakukan dengan objek tersebut.

Mitchelmore dan White (2007) secara garis besar membedakan abstraksi menjadi dua jenis yaitu abstraksi empiris dan abstraksi teoritis. Abstrasi empiris berhubungan erat dengan pengalaman empiris. Pembentukan 
pengertian suatu objek yang abstrak berdasarkan pada pengalaman sosial dan fisik anak. Sedangkan abstraksi teoritis, pembentukan konsep-kosep berdasarkan pada suatu teori.

Pengalaman empiris siswa berpengaruh dalam proses pembelajaran matematika. Siswa dapat memahami suatu konsep ketika permasalahan yang diberikan sesuai dengan pengalamannya dalam kehidupan sehari-hari siswa. Selain itu, siswa juga dapat membangun konsep-konsep berdasarkan teori sebelumnya yang sudah dikuasai.

Tata (2015) mengungkapkan indikator kemampuan abstraksi reflektif, abstraksi empiris dan abstraksi teoritis. Indikator untuk masingmasing jenis abstraksi sebagai berikut:

\section{Tabel 1}

Indikator Kemampuan Abstraksi Matematis

\begin{tabular}{|l|l|}
\hline \multicolumn{1}{|c|}{ Jenis Abstraksi } & \multicolumn{1}{|c|}{ Indikator Kemampuan Abstraksi } \\
\hline Abstraksi Reflektif & $\begin{array}{l}\text { 1. Pengintegrasiaan dan perumusan } \\
\text { masalah. }\end{array}$ \\
& $\begin{array}{l}\text { 2. Transformasi masalah ke dalam } \\
\text { bentuk simbol. }\end{array}$ \\
\hline Abstraksi Empiris & $\begin{array}{l}\text { 3. Membuat generalisasi. } \\
\text { 4. Pembentukan konsep matematika } \\
\text { terkait konsep yang lain. }\end{array}$ \\
& $\begin{array}{l}\text { 5. Pembentukan objek matematika } \\
\text { lebih lanjut. }\end{array}$ \\
\hline Abstraksi Teoritis & 6. Formalisasi objek matematika. \\
\hline
\end{tabular}

Berdasarkan beberapa pendapat yang telah dikemukakan, jenis abstraksi dalam penelitian ini adalah abstraksi reflektif, abstraksi empiris dan abstraksi teoritis. Adapun indikator kemampuan abstraksi matematis dalam penelitian ini yaitu: (1) kemampuan siswa mentransformasi masalah ke dalam bentuk simbol; (2) kemampuan siswa membuat persamaan yang setara; (3) kemampuan siswa menyatakan hubungan antara konsep bangun datar dengan persamaan linear; (4) kemampuan siswa membuat generalisasi; dan (5) kemampuan siswa membuat persamaan sesuai dengan situasi yang diberikan.

\section{METODE PENELITIAN}

Jenis penelitian ini adalah kualitatif deskriptif. Maleong (Mujib, A. \& Suparingga, E; 2013) menyatakan bahwa penelitian kualitatif adalah penelitian untuk memahami fenomena tentang apa yang dialami oleh subjek penelitian misalnya perilaku, persepsi, motivasi, tindakan, dan lainnya secara holistik dan dengan cara deskripsi dengan kata-kata dan bahasa, pada suatu konteks khusus yang alamiah dan dengan memanfaatkan berbagai metode ilmiah. Penelitian ini merupakan studi pendahuluan yang dilaksanakan di salah satu Sekolah Menengah Pertama Negeri (SMPN) Kota Bandung. Penelitian dilaksanakan di 
kelas VIII pada semester ganjil tahun pelajaran 2015/2016 dengan subyek penelitian berjumlah 33 orang. Instrumen utama dalam penelitian ini adalah peneliti sendiri dan dibantu dengan tes kemampuan abstraksi matematis serta pedoman wawancara.

Teknik pengumpulan data dalam penelitian ini adalah teknik tes. Teknis tes digunakan untuk mendapatkan hasil pekerjaan siswa dalam menyelesaikan soal kemampuan abstraksi matematis. Hasil tes dianalisis menggunakan analisis data kualitatif yang didasarkan pada indikator kemampuan abstraksi matematis. Selanjutnya dilaksanakan wawancara untuk mendalami kemampuan abstraksi matematis siswa. Pengujian keabsahan data penelitian menggunakan triangulasi. Analisis data dilakukan dengan cara penyajian data, reduksi data dan penarikan kesimpulan.

\section{HASIL DAN PEMBAHASAN}

Penentuan subyek dalam penelitian ini diawali dengan memilih satu sekolah yang sebelumnya berada pada level atas di kota Bandung. Selanjutnya memilih salah satu kelas VIII di sekolah tersebut. Secara umum siswa kelas VIII pada sekolah tersebut memiliki karakteristik yang sama. Kelas yang menjadi subyek penelitian adalah kelas VIII-H.

Peneliti memberikan tes kemampuan abstraksi matematis untuk mengetahui kemampuan siswa dalam menyelesaikan soal abstraksi matematis pada materi persamaan linear satu variabel (PLSV). Materi PLSV sudah dipelajari siswa di kelas VII pada semester 1. Berdasarkan analisis terhadap hasil pekerjaan siswa dari lima indikator abstraksi matematis yang diberikan, ternyata belum sesuai dengan yang diharapkan. Namun tiga indikator terakhir cenderung jauh lebih rendah dari indikator pertama dan kedua, yaitu menyatakan hubungan antara konsep bangun datar dengan persamaan linear, membuat generalisasi, dan membuat persamaan sesuai dengan situasi yang diberikan. Siswa cenderung masih kesulitan dalam menyelesaikan soal tersebut. Analisis terhadap hasil tes, diperoleh rata-rata kemampuan abstraksi matematis siswa sebesar 9,5 dari skor ideal 20. Persentase rata-rata kemampuan abstraksi matematis siswa hanya 47,5\% dari skor maksimal ideal. Untuk lebih jelasnya, hasil pekerjaan siswa dalam menyelesaikan soal yang diberikan pada indikator menyatakan hubungan antara konsep bangun datar dengan persamaan linear, membuat generalisasi, dan membuat persamaan sesuai dengan situasi yang diberikan, disajikan pada Tabel 2, Tabel 3, dan Tabel 4 berikut.

1. Kemampuan siswa menyatakan hubungan antara konsep bangun datar dengan persamaan linear

Tabel 2 berikut menggambarkan secara rinci kemampuan siswa dalam menyelesaikan soal kemampuan abstraksi matematis pada indikator kemampuan siswa menyatakan hubungan antara konsep bangun datar dengan persamaan linear. 
Tabel 2

Menyatakan Hubungan antara Konsep Bangun Datar dengan Persamaan Linear

\begin{tabular}{|l|c|c|}
\hline \multicolumn{1}{|c|}{$\begin{array}{c}\text { Menyatakan hubungan antara konsep bangun } \\
\text { datar } \\
\text { dengan persamaan linear }\end{array}$} & $\begin{array}{c}\text { Banyak } \\
\text { Siswa }\end{array}$ & $\begin{array}{c}\text { Persentase } \\
(\%)\end{array}$ \\
\hline Tidak ada jawaban & 15 & 45,45 \\
\hline Menuliskan unsur-unsur yang diketahui & 4 & 12,12 \\
\hline $\begin{array}{l}\text { Menuliskan unsur-unsur yang diketahui dan membuat } \\
\text { model matematis }\end{array}$ & 6 & 18,18 \\
\hline $\begin{array}{l}\text { Menuliskan unsur-unsur yang diketahui, membuat } \\
\text { model matematis, melakukan perhitungan namun tidak } \\
\text { tuntas atau perhitungannya belum tepat }\end{array}$ & 5 & 15,15 \\
\hline $\begin{array}{l}\text { Menuliskan unsur-unsur yang diketahui, membuat } \\
\text { model matematis, melakukan perhitungan dengan } \\
\text { tepat dan membuat kesimpulan }\end{array}$ & 3 & 9,09 \\
\hline Jumlah & 33 & 100 \\
\hline
\end{tabular}

Berdasarkan Tabel 2, hanya 9,09 \% siswa yang dapat menuliskan unsur-unsur yang diketahui, membuat model matematis, melakukan perhitungan dan membuat kesimpulan dengan tepat dari permasalahan yang diberikan. Secara keseluruhan, jika dihubungkan dengan ketuntasan belajar siswa, hanya 8 siswa atau 24,24\% siswa yang mendapat nilai $\geq 75$. Selain itu, pada indikator ini sebanyak 15 siswa atau 45,45\% siswa tidak memberikan jawaban. Alasan siswa tersebut tidak memberikan jawaban adalah tidak mengerti permasalahan yang diberikan dan sudah lupa dengan materi yang berhubungan dengan permasalahan tersebut.

2. Kemampuan siswa membuat generalisasi

Tabel 3 berikut menggambarkan secara rinci kemampuan siswa dalam menyelesaikan soal kemampuan abstraksi matematis pada indikator kemampuan siswa membuat generalisasi.

Tabel 3

Membuat Generalisasi

\begin{tabular}{|l|c|c|}
\hline \multicolumn{1}{|c|}{ Membuat Generalisasi } & $\begin{array}{c}\text { Banyak } \\
\text { Siswa }\end{array}$ & $\begin{array}{c}\text { Persentase } \\
(\mathbf{\%})\end{array}$ \\
\hline Tidak ada jawaban & 19 & 57,57 \\
\hline Jawaban kurang lengkap dan kurang jelas & 10 & 30,30 \\
\hline $\begin{array}{l}\text { Jawaban hampir lengkap dan jelas namun } \\
\text { penyajian tidak sistematis }\end{array}$ & 4 & 12,12 \\
\hline $\begin{array}{l}\text { Jawaban hampir lengkap dan jelas serta } \\
\text { penyajian sistematis }\end{array}$ & 0 & 0,00 \\
\hline $\begin{array}{l}\text { Jawaban lengkap dan jelas serta } \\
\text { penyajian tepat dan sistematis }\end{array}$ & 0 & 0,00 \\
\hline Jumlah & 33 & 100 \\
\hline
\end{tabular}


Berdasarkan Tabel 3, tidak ada siswa yang dapat memberikan jawaban lengkap dan jelas serta penyajian tepat dan sistematis. Bahkan sebanyak $57,57 \%$ siswa tidak memberikan jawaban. Secara umum alasan siswa tidak memberikan jawaban adalah karena tidak mengerti dengan permasalahan yang diberikan dan lupa dengan materi yang terkait dengan permasalahan tersebut.

3. Kemampuan siswa membuat persamaan sesuai dengan situasi yang diberikan

Tabel 4 berikut menggambarkan secara rinci kemampuan siswa dalam menyelesaikan soal kemampuan abstraksi matematis pada indikator membuat persamaan sesuai dengan situasi yang diberikan.

Tabel 4

Membuat Persamaan Sesuai dengan Situasi yang Diberikan

\begin{tabular}{|l|c|c|}
\hline \multicolumn{1}{|c|}{ Membuat Generalisasi } & $\begin{array}{c}\text { Banyak } \\
\text { Siswa }\end{array}$ & $\begin{array}{c}\text { Persentase } \\
(\mathbf{\%})\end{array}$ \\
\hline Tidak ada jawaban & 10 & 30,30 \\
\hline Membuat persamaan tetapi belum tepat & 4 & 12,12 \\
\hline $\begin{array}{l}\text { Membuat persamaan sesuai dengan situasi yang } \\
\text { diberikan tetapi belum lengkap }\end{array}$ & 6 & 18,18 \\
\hline $\begin{array}{l}\text { Membuat persamaan sesuai dengan situasi yang } \\
\text { diberikan hampir lengkap }\end{array}$ & 12 & 36,36 \\
\hline $\begin{array}{l}\text { Membuat persamaan sesuai dengan situasi yang } \\
\text { diberikan dengan lengkap dan tepat }\end{array}$ & 1 & 3,03 \\
\hline Jumlah & 33 & 100 \\
\hline
\end{tabular}

Berdasarkan Tabel 4, secara keseluruhan jika dihubungkan dengan ketuntasan belajar siswa, maka 13 siswa atau 39,39\% siswa mendapat nilai $\geq$ 75. Pada indikator ini, semua siswa memberikan jawaban, artinya $0 \%$ siswa yang tidak memberikan jawaban. Namun demikian, siswa yang nilainya kurang dari 75 jauh lebih banyak. Hal ini berarti siswa masih kesulitan menyelesaikan soal yang berkaitan dengan indikator membuat persamaan sesuai dengan situasi yang diberikan.

\section{E. KESIMPULAN DAN SARAN}

Berdasarkan paparan yang telah dikemukakan, dapat disimpulkan bahwa kemampuan abstraksi matematis siswa di salah satu SMPN Kota Bandung Kelas VIII cenderung masih rendah pada materi PLSV. Tiga indikator abstraksi matematis terakhir cenderung jauh lebih rendah dari indikator pertama dan kedua, yaitu menyatakan hubungan antara konsep bangun datar dengan persamaan linear, membuat generalisasi, dan membuat persamaan sesuai dengan situasi yang diberikan. Kemampuan membuat generalisasi merupakan kemampuan yang dianggap paling sulit oleh siswa. Penyebab kesulitan siswa dalam menyelesaikan soal abstraksi matematis adalah kurang cermat dalam membaca permasalahan soal cerita, kesulitan 
menghubungkan antar konsep dan retensi siswa cenderung lemah. Pada hasil penelitian ini memberikan saran atau rekomendasi kepada para guru dan peneliti untuk memperhatikan hal-hal berikut dalam pembelajaran, yaitu: 1) pemilihan model atau pendekatan pembelajaran harus tepat sesuai dengan karakteristik materi dan karakteristik siswa; 2) penggunaan model pembelajaran bervariasi; 3) penggunaan bahan ajar lebih mengaktifkan siswa; dan 4) pemberian bantuan dalam proses pembelajaran harus dilakukan secara bertahap (scaffolding).

\section{F. DAFTAR PUSTAKA}

Bermejo \& Diaz (2007). The Degree of Abstraction in Solving Addition and Subtraction Problems. The Spanish Journal of Psychology: Vol. 10, No. 2, 285-293.

Hong, Y.J. \& Kim, K.M. ( 2016). Mathematical Abstraction. The Solving illStructured Problems by Elementary School Students in Korea. Eurasia Journal of Mathematics, Science \& Technology Education: Vol. 12, No.2, 267-281.

Mitchelmore, M., White, P. (2007). Abstraction in Mathematics Learning. Mathematics Education Research Journal: Vol. 19, No. 2, 1-9.

Mujib, A. \& Suparingga, E. (2013). Upaya Mengatasi Kesulitan Siswa dalam Operasi Perkalian dengan Metode Latis. Prosiding Seminar Nasional Matematika dan Pendidikan Matematika (hal. 1-6). Yogyakarta: Jurusan Pendidikan Matematika FMIPA UNY

The Program for International Student Assessment (PISA) (2015). Result and Focus. [Online]. Diakses dari https://www.oecd.org/pisa/pisa-2015results-in-focus.pdf

Tata. (2015). Peningkatan Kemampuan Pemodelan dan Abstraksi Matematis serta Motivasi Belajar Siswa Sekolah Menengah Pertama Melalui Pembelajaran Kontekstual Kolaboratif. Disertasi, Sekolah Pascasarjana, Universitas Pendidikan Indonesia, Bandung. 